\title{
PENGARUH MODEL PEMBELAJARAN BERBASIS MASALAH TERHADAP HASIL BELAJAR KOGNITIF SISWA KELAS VII SMP
}

\author{
Insar Damopolii' ${ }^{1)}$, Aksamina M. Yohanita ${ }^{1)}$, Febilia H. Malatta ${ }^{1)}$, Frida M. Yusuf ${ }^{2)}$ \\ ${ }^{1}$ Jurusan Pendidikan Biologi, Universitas Papua, Jl. Gunung Salju, Amban, Manokwari \\ ${ }^{2}$ Jurusan Biologi, Universitas Negeri Gorontalo, Jl. Jendral Sudirman, Gorontalo \\ e-mail: i.damopoli@unipa.ac.id
}

\begin{abstract}
The purpose of research to determine that effect of problem-based learning (PBL) model on cognitive student achievement in SMP YPPGI Silo Manokwari in the relation of population density to the environment topic. The study was a quasi-experimental research used nonequivalent control group design. The sample of the study was the students of class VIIA such as experimental class and the total students as many as 23 students and the class VIIB such as the control class and the total students as many as 22 students. That result showed the experimental class to implementation PBL model obtained the average posttest 70,78, while the class control obtained the average posttest 50,05 . The significant value was $0,01<\alpha=0,05$, there were different cognitive student achievement between the experiment class and the control class. Conclusion, there are differences in cognitive students achievement between students taught using PBL model with students taught using a conventional learning model.
\end{abstract}

Keywords: Problem based learning model, Student achievement

\section{PENDAHULUAN}

Belajar merupakan unsur yang sangat mendasar dalam penyelenggaraan di semua jenjang pendidikan. Keberhasilan pencapaian tujuan pendidikan bergantung pada keberhasilan suatu proses belajar yang dilaksanakan di sekolah dan dukungan lingkungan sekitarnya. Proses belajar dapat terjadi karena interaksi seseorang dengan lingkungannya yang akan menghasilkan suatu perubahan tingkah laku pada berbagai aspek, diantaranya pengetahuan, sikap, dan keterampilan.

Pada kegiatan belajar mengajar di dalam kelas terjadi proses penilaian yang akan menentukan tingkat pengetahuan serta mengukur ketercapaian belajar siswa. Hasil belajar merupakan faktor yang sangat penting, karena hasil belajar yang dicapai siswa merupakan alat untuk mengukur sejauh mana siswa menguasai materi yang diajarkan oleh guru. Terdapat tiga faktor yang mempengaruhi keberhasilan proses dan hasil belajar, yaitu faktor internal (faktor dari dalam individu), faktor eksternal (faktor dari luar individu), dan faktor pendekatan belajar yakni jenis upaya belajar siswa yang meliputi strategi dan metode yang digunakan siswa untuk melakukan kegiatan mempelajari materi-materi pelajaran (Slameto, 2013).

Selain faktor keberhasilan pada proses belajar, yang perlu diperhatikan dalam pendidikan adalah kualitas pembelajaran. Pengembangan kualitas pembelajaran dilakukan untuk mengamati keaktifan siswa dalam proses belajar mengajar dan kualitas hasil belajar. Penerapan model pembelajaran yang efektif di dalam kelas diharapkan mampu memperbaiki dengan baik hasil belajar dan memberdayakan potensi yang 
dimiliki oleh siswa. Penerapan model pembelajaran yang bervariasi sangat dibutuhkan pada pelajaran sains seperti halnya pada pelajaran biologi. Untuk dapat mewujudkan siswa yang memiliki sikap aktif, kreatif, inovatif dan berwawasan luas dan berdampak pada hasil belajar siswa, maka guru harus berperan aktif dalam menciptakan kondisi belajar yang membuat siswa aktif dan termotivasi dalam proses kegiatan belajar mengajar (Damopolii \& Nunaki, 2016).

Berdasarkan hasil observasi yang telah dilaksanakan di SMP YPPGI Silo Manokwari, ditemukan permasalahan dalam proses pembelajaran biologi. Salah satu permasalahan yang terjadi adalah rendahnya hasil belajar siswa pada materi hubungan kepadatan populasi terhadap lingkungan. Kondisi pembelajaran masih berlangsung satu arah karena guru masih berpatokan pada pembelajaran yang bersifat konvensional seperti penggunaan ceramah dan diskusi. Hasil belajar siswa pada materi hubungan kepadatan populasi terhadap lingkungan pada tahun ajaran 2015/2016 yaitu dari 25 siswa kelas VII hanya $35 \%$ yang mencapai KKM 60 .

Rendahnya hasil belajar biologi siswa disebabkan oleh ketidaktepatan penggunaan model pembelajaran yang digunakan guru di kelas. Perbaikan kualitas pembelajaran biologi salah satunya ditempuh melalui perbaikan terhadap model pembelajaran yang digunakan oleh guru dalam mengajar (Kusumaningtias, Zubaidah, \& Indriwati, 2013). Kenyataan menunjukkan bahwa selama ini guru mata pelajaran biologi lebih cenderung menggunakan model pembelajaran yang tidak bervariasi. Guru mendominasi pembelajaran dan lebih fokus menjelaskan konsep materi pelajaran tanpa memperhatikan kondisi kelas, sehingga siswa merasa jenuh, tidak bersemangat dan pasif.
Guru kurang memberi kesempatan kepada siswa untuk berhubungan dengan lingkungan alam sekitar, menelaah dan berpendapat mengenai konsep yang ada. Akibatnya suasana kelas selama pembelajaran cenderung pasif, aktifitas siswa rendah, kurang kondusif, efektif dan siswa tidak aktif dalam bertanya. Konsep pembelajaran saat ini harus berubah dari pembelajaran yang berpusat pada guru (Teacher centered learning) menjadi pembelajaran yang berpusat pada siswa (Student centered learning) (Baransano, Yohanita, \& Damopolii, 2017). Pembelajaran pada abad 21 lebih menekankan pada pembelajaran berpusat pada siswa, dimana guru hanya menjadi fasilitator dan memotivasi siswa dalam belajar.

Berdasarkan hasil observasi yang diuraikan, dibutuhkan model pembelajaran yang dapat menarik minat siswa untuk mempelajari materi hubungan kepadatan populasi terhadap lingkungan, sehingga dapat menghidupkan suasana kelas dan meningkatkan hasil belajar siswa. Model yang digunakan harus sesuai dengan tujuan pembelajaran serta jenis materi yang diajar. Guru diharapkan dapat menemukan dan mengembangkan ide dalam diri siswanya, artinya guru diharapkan dapat mampu meningkatkan kemampuan berpikir dan memecahkan masalah siswa dalam mempelajari materi hubungan kepadatan populasi terhadap lingkungan. Salah satu model pembelajaran yang dapat membantu siswa berlatih memecahkan masalah adalah model pembelajaran berbasis masalah (PBM). Model PBM merupakan model pembelajaran yang membawa siswa pada masalah autentik (nyata), sehingga siswa dapat menyusun dan mengembangkan pengetahuannya sendiri. Menurut Damopolii, Nunaki \& Supriyadi (2018) bahwa mengajar 
tidak ditentukan oleh selera guru, akan tetapi sangat ditentukan oleh siswa itu sendiri.

Peran guru pada model PBM adalah memberikan masalah kepada siswanya untuk dipecahkan secara kelompok. PBM banyak melibatkan siswa secara aktif dalam proses pembelajaran. Pengajar di dalam kelas pembelajaran berbasis masalah memfasilitasi proses pembelajaran dengan memantau kemajuan peserta didik dan mengajukan pertanyaan untuk mendorong siswa maju dalam proses pemecahan masalah (Major \& Palmer, 2001). Dengan mengukur kesadaran masalah yang dirasakan dari sudut pandang siswa, guru akan dapat mengeksplorasi sejauhmana keterlibatan pembelajaran berbasis masalah dan efektivitasnya (Scott, 2014).

Menurut Hallinger \& Lu (2011) bahwa siswa menganggap pembelajaran berbasis masalah sebagai pembelajaran yang efektif. Siswa diberikan kebebasan untuk lebih berpikir kreatif dan aktif berpartisipasi dalam menggunakan dan mengembangkan penalarannya mengenai materi hubungan kepadatan populasi terhadap lingkungan serta mampu menggunakan penalarannya dalam menyelesaikan suatu permasalahan yang dihadapinya dalam kehidupan sehari-hari. Pembelajaran berbasis masalah adalah suatu model pembelajaran yang menuntut peserta didik untuk berpikir kritis, memecahkan masalah, belajar secara mandiri, dan menuntut keterampilan berpartisipasi dalam tim (Riyanto, 2010). Siswa dapat dilatih menjadi pembelajar yang aktif dan dilatih untuk membangun pengetahuan mereka melalui pembelajaran berbasis masalah (Yu $\mathrm{dkk}$, 2005). Pemecahan masalah sangat penting bagi masa depan siswa (Damopolii, Hasan, \& Kandowangko, 2015).

Beberapa penelitian yang telah dilakukan menunjukkan bahwa terdapat pengaruh model pembelajaran berbasis masalah terhadap hasil belajar siswa, dimana siswa yang diajarkan dengan menggunakan model pembelajaran berbasis masalah ratarata hasil belajarnya lebih tinggi dibandingkan dengan siswa yang diajarkan menggunakan pembelajaran konvensional (Kinaseh dkk, 2015; Sari \& Harahap, 2015; Wahyudi dkk, 2015; Yusuf \& Pujiastutik, 2017; Günter \& Alpat, 2017). Pembelajaran berbasis masalah merupakan model pembelajaran aktif yang efektif untuk meningkatkan prestasi dan mencegah terbentuknya suatu alternatif konsepsi, keterbatasan konseptual dan kurangnya pengetahuan siswa (Ayyildiz \& Tarhan, 2018).

Dengan banyaknya aktifitas yang dilakukan oleh siswa, diharapkan dapat menimbulkan rasa senang dan antusias siswa dalam belajar. Dengan demikian diharapkan dapat berpengaruh terhadap pemahaman siswa pada materi hubungan kepadatan populasi terhadap lingkungan yang dapat mendorong siswa untuk meningkatkan hasil belajarnya.

\section{METODE PENELITIAN}

Penelitian dilaksanakan di SMP YPPGI Silo Manokwari. Jenis penelitian adalah kuasi eksperimen dengan menggunakan nonequivalent control group design. Jumlah kelas yang menjadi sampel penelitian sebanyak dua kelas. Satu kelas kontrol (kelas VIIB) yaitu kelas yang diajarkan dengan menggunakan model pembelajaran konvensional dan satu kelas eksperimen (kelas VIIA) yang diajarkan dengan menggunakan model pembelajaran berbasis masalah (PBM). Jumlah siswa sebanyak 45 orang dimana kelas eksperimen berjumlah 23 siswa dan kelas kontrol berjumlah 22 siswa. Tabel berikut merupakan desain penelitian yang digunakan: 
Tabel 1. Nonequivalent Control Group Design

\begin{tabular}{ccc}
\hline Pretest & Perlakuan & Posttest \\
\hline $\mathrm{O}_{1}$ & $\mathrm{X}$ & $\mathrm{O}_{2}$ \\
$\mathrm{O}_{3}$ & & $\mathrm{O}_{4}$ \\
\hline \multicolumn{3}{c}{ (Sugiyono, 2015) }
\end{tabular}

Keterangan:

O1 : Pretest kelas eksperimen

$\mathrm{O} 2$ : Posttest kelas eksperimen

O3 : Pretest kelas kontrol

O4 : Posttest kelas kontrol

$\mathrm{X}$ : Perlakuan dengan penerapan model pembelajaran berbasis masalah

Instrumen yang digunakan dalam penelitian ini adalah silabus dan RPP yang terdiri dari RPP kelas eksperimen dan RPP kelas kontrol, soal tes untuk pretest dan posttest, lembar observasi kegiatan guru, dan lembar kerja siswa (LKS). Sebelum digunakan, soal tes untuk pretest dan posttest diujicobakan untuk menentukan nilai reliabilitasnya. Hasil uji coba soal pretest dan posttest memperoleh nilai reliabilitas sebesar 0,78 yang menandakan soal reliabel dan dapat digunakan untuk mengukur hasil belajar kognitif siswa.

Tes digunakan untuk mengukur hasil belajar siswa sebelum dan setelah diterapkannya model pembelajaran perbasis masalah (PBM). Tes ini disusun berdasarkan indikator yang hendak dicapai. Soal-soal tes yang digunakan berupa soal pilihan ganda pada konsep hubungan kepadatan populasi terhadap lingkungan. Instrumen ini mencakup ranah kognitif pada aspek pengetahuan (C1) sampai analisis (C4). Bentuk tes yang digunakan dalam penelitian adalah adalah tes objektif berbentuk pilihan ganda dengan 4 option sebanyak 15 soal. Uji normalitas menggunakan uji Shapiro-wilk dan uji homogenitas menggunakan uji Levene dengan $\alpha=0,05$. Uji hipotesis dalam penelitian ini menggunakan Independent Samplet $t$ Test. Keseluruhan analisis data menggunakan bantuan softwere SPSS 22 for Windows 2010.

\section{HASIL DAN PEMBAHASAN}

Data yang disajikan dalam penelitian yaitu data rata-rata hasil belajar kognitif siswa kelas eksperimen dan kelas kontrol, persentase hasil belajar kognitif siswa, data hasil uji normalitas dan homogenitas data serta data hasil uji t. Keseluruhan data ditampilkan sebagai berikut:

Tabel 2. Persentase Hasil Belajar Kelas Eksperimen

\begin{tabular}{cccc}
\hline Nilai & Keterangan & $\mathbf{f}$ & $\begin{array}{c}\mathbf{P}(\mathbf{f} / \mathbf{N} * \mathbf{1 0 0}) \\
(\mathbf{\%})\end{array}$ \\
\hline $80-100$ & Sangat Baik & 7 & 30,43 \\
$70-79$ & Baik & 14 & 17,39 \\
$60-69$ & Cukup & 10 & 43,48 \\
$40-59$ & Kurang & 2 & 8,70 \\
$0-39$ & Sangat Kurang & 0 & 0,00 \\
\hline & $\mathbf{N}=\mathbf{2 3}$ & & $\mathbf{1 0 0 , 0 0}$ \\
\hline
\end{tabular}


Vol. 3, No. 1 : Hal 43-52

Februari 2018

Berdasarkan data pada Tabel 2, siswa pada kelas eksperimen memperoleh menunjukkan bahwa hasil belajar kognitif nilai sangat baik karena lebih dari $80 \%$ siswa pada kelas eksperimen yang siswa memperoleh nilai di atas KKM 60. berkategori cukup - sangat baik mencapai Rata-rata hasil belajar kognitif siswa pada 91,30 \% dari total siswa. Hal ini kelas eksperimen adalah 70,78. menunjukkan bahwa hasil belajar kognitif

Tabel 3. Persentase hasil belajar siswa kelas kontrol

\begin{tabular}{cccc}
\hline Nilai & Keterangan & $\mathbf{f}$ & $\begin{array}{c}\mathbf{P}(\mathbf{f} / \mathbf{N} * \mathbf{1 0 0}) \\
(\mathbf{\%})\end{array}$ \\
\hline $80-100$ & Sangat Baik & 0 & 0,00 \\
$70-79$ & Baik & 0 & 0,00 \\
$60-69$ & Cukup & 6 & 22,27 \\
$40-59$ & Kurang & 14 & 63,64 \\
$0-39$ & Sangat Kurang & 2 & 9,09 \\
\hline & $\mathbf{N}=\mathbf{2 2}$ & & $\mathbf{1 0 0 , 0 0}$ \\
\hline
\end{tabular}

Berdasarkan data pada Tabel 3, kurang karena kurang dari $80 \%$ siswa menunjukkan bahwa hasil belajar kognitif memperoleh nilai di atas KKM 60. Rata-rata siswa pada kelas eksperimen yang hasil belajar kognitif siswa pada kelas berkategori cukup - sangat baik mencapai eksperimen adalah 50,05. Perbandingan $27,27 \%$ dari total siswa. Hal ini hasil belajar kognitif siswa pada kelas menunjukkan bahwa hasil belajar kognitif eksperimen dan kelas kontrol disajikan pada siswa pada kelas kontrol memperoleh nilai grafik berikut:

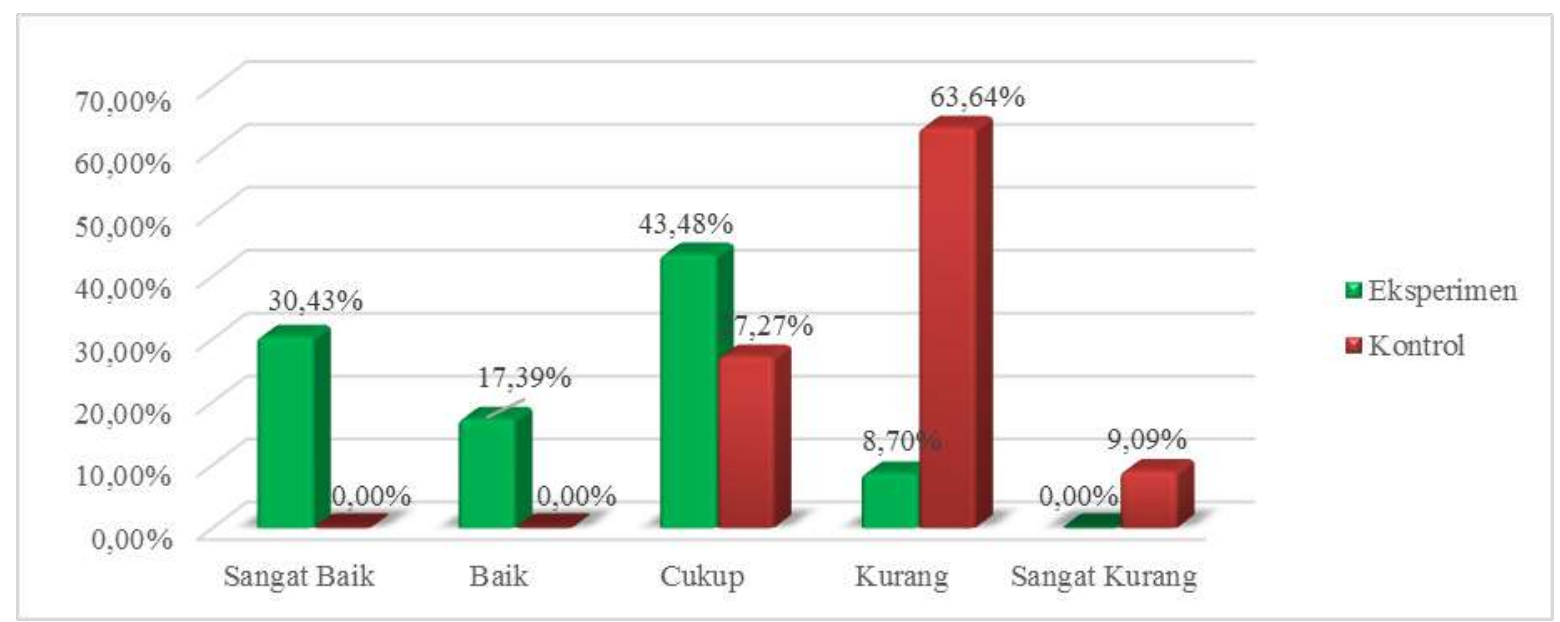

Gambar 1. Grafik Perbandingan Persentase Hasil Belajar Kelas Eksperimen dan Kontrol

Tabel 4. Hasil Uji Normalitas Posttest Kelas Eksperimen dan Kontrol

\begin{tabular}{cccccc}
\hline Data & Statistik & Derajat bebas & Sig. & a & Keterangan \\
\hline Eksperimen & 0,966 & 23 & 0,606 & 0,05 & Normal \\
Kontrol & 0,932 & 22 & 0,134 & 0,05 & Normal \\
\hline
\end{tabular}

Uji normalitas pada Tabel 4 ini menandakan bahwa data hasil belajar menunjukkan bahwa nilai sig posttest pada kognitif siswa pada kelas eksperimen kelas eksperimen sebesar $0,606>0,05$, hal berdistribusi normal. Nilai sig posttest pada 
kelas kontrol sebesar $0,134>0,05$, hal ini menandakan bahwa data posttest kelas lengkap untuk uji homogenitas kedua kelas kontrol terdistribusi normal.

dapat dilihat pada Tabel rekapitulasi berikut:

Dalam penelitian ini uji homogenitas

menggunakan uji levene. Perhitungan secara

Tabel 5. Hasil Uji Homogenitas Posttest Kelas Eksperimen dan Kontrol

\begin{tabular}{ccccccc}
\hline Data Posttest & $\begin{array}{c}\text { Levene } \\
\text { Statistik }\end{array}$ & df1 & df2 & Sig. & a & Keterangan \\
\hline Based on Mean & 0,808 & 1 & 43 & 0,374 & 0,05 & Homogen \\
\hline
\end{tabular}

Uji homogenitas pada Tabel 5 menunjukkan bahwa nilai sig pada posttest kelas eksperimen dan kelas kontrol sebesar 0,374 >
0,05, sesuai dengan kriteria bahwa jika sig > dari 0,05 , maka data homogen.

Tabel 6. Data hasil perbedaan posttest kelas eksperimen dan kontrol

\begin{tabular}{ccccccc}
\hline \multirow{2}{*}{ Posttest } & Data & $\mathbf{t}$ & $\begin{array}{c}\text { Derajat } \\
\text { bebas }\end{array}$ & Sig. & a & Keterangan \\
\cline { 2 - 6 } & $\begin{array}{c}\text { Equal variances } \\
\text { assumed }\end{array}$ & 6,886 & 43 & 0,000 & 0,05 & Ada perbedaan \\
\hline
\end{tabular}

Hasil analisis data pada Tabel 6 menunjukkan bahwa signifikan untuk posttest kelas eksperimen dan kelas kontrol pada equal variances assumed yaitu 0,000 < 0,05 maka dinyatakan ada perbedaan nilai rata-rata hasil belajar kognitif siswa pada kelas eksperimen (siswa yang diajarkan dengan menggunakan PBM) dan kontrol (siswa yang diajarkan dengan menggunakan pembelajaran konvensional).

Berdasarkan data hasil penelitian menunjukkan bahwa pembelajaran dengan menggunakan model PBM pada materi hubungan kepadatan populasi terhadap lingkungan telah mampu meningkatkan pemahaman konsep siswa. Hal tersebut dapat dilihat dari hasil belajar kognitif siswa melalui nilai posttest. Hasil belajar kognitif siswa pada kelas eksperimen lebih tinggi dibandingkan kelas kontrol, dikarenakan pada penerapan model PBM guru memberikan permasalahan untuk dipecahkan oleh siswa, sedangkan kelas kontrol tidak diberi perlakuan apapun hanya menggunakan pembelajaran konvensional.
Perbedaan hasil belajar kognitif siswa yang diperoleh dalam penelitian ini sejalan dengan dengan penelitian yang telah dilaksanakan oleh Taşoğlu \& Bakaç (2014); Kono, Mamu, \& Tangge (2016); Irawan, Susanna, \& Hamid (2017) yang menemukan bahwa ada pengaruh penggunaan model PBM terhadap pemahaman konsep siswa. Model PBM merupakan model pembelajaran yang lebih baik digunakan dalam proses belajar mengajar di kelas dibandingkan dengan model pembelajaran konvensional.

PBM merupakan inovasi dalam pembelajaran, karena dalam pembelajaran dengan menggunakan PBM kemampuan berfikir siswa dioptimalisasikan melalui proses kerja kelompok, sehingga siswa dapat memberdayakan, mengasah, menguji dan mengembangkan kemampuan berfikirnya secara berkesinambungan (Rusman, 2012). Siswa di kelas eksperimen yang dibelajarkan dengan PBM lebih aktif dalam mengikuti proses pembelajaran di kelas. Model pembelajaran yang digunakan dalam kelas eksperimen membuat siswa lebih paham dan tertarik untuk belajar. Permasalahan yang 
disajikan oleh guru berupa permasalah yang dihadapi di masyarakat yaitu tentang kepada populasi suatu daerah yang dimuat dalam berita salah satu koran. Siswa diminta untuk memecahkan masalah yang diberikan oleh guru secara berkelompok. Aktivitas belajar siswa menjadi lebih baik, dapat saling bertukar pendapat yang mendorong kemauan siswa untuk menyelesaikannya dan membuat siswa lebih giat belajar. Pada kelas kontrol yaitu diajarkan menggunakan model pembelajaran konvensional masih terfokus pada metode ceramah dan diskusi yang membuat minat belajar siswa menjadi berkurang. Terbukti pada hasil belajar siswa pada kelas kontrol yang rendah.

Model PBM adalah sebuah alternatif pembelajaran yang dapat meningkatkan hasil belajar siswa (Argaw, Haile, Ayalew, \& Kuma, 2017). Siswa menjadi aktif dalam proses pembelajaran menggunakan PBM dibandingkan dengan siswa pada model pembelajaran konvensional, dan guru memperhatikan bahwa dalam PBM siswa belajar secara teratur lebih dari siswa pada kelas konvensional (Wijnen dkk, 2017). Pada penelitian yang telah dilaksanakan terlihat bahwa keterlibatan aktif siswa pada tahap pemecahan masalah yang diberikan oleh guru dapat membangun pengetahuan yang dimiliki siswa. Begitupun pengelompokkan dalam belajar dapat memfasilitasi siswa untuk saling berkolaborasi, saling tukar pikiran, saling mengajari serta dapat menyelesaikan masalah dengan banyak cara, dan menimbulkan berbagai pemikiran yang berbeda. Proses presentasi yang dilakukan dalam kelompok juga membuat siswa lebih memahami lagi masalah yang ada.

Kelas eksperimen memiliki hasil belajar yang lebih tinggi karena diberikan model PBM. Pembelajaran dengan PBM dimulai dari suatu permasalahan, kemudian para siswa diorganisasikan dalam suatu kelompok kecil. Dalam kelompok tersebut, siswa berdiskusi untuk menentukan penyelesaian masalah dengan memanfaatkan pengetahuan yang mereka miliki. Pada tahap inilah kemampuan berpikir kreatif siswa untuk mengingat dan memahami dilatih. Kebiasaan berpikir yang baik menimbulkan pertanyaan untuk mengarahkan pembelajaran mereka sendiri, dengan mempertimbangkan berbagai macam dan beragam terhadap sebuah masalah, mencari tahu bagaimana memecahkan masalah melalui berbagai jenis penyelidikan, dan berpikir secara mandiri (Chin \& Chia, 2006).

Menurut Günter, Akkuzu, \& Alpat (2017) bahwa ada pendapat positif siswa dalam pembelajaran menggunakan model PBM yaitu ketertarikan mereka pada permasalahan yang diberikan oleh guru, karena masalah yang diberikan terkait dengan fenomena kehidupan sehari-hari. Ketika siswa dapat mampu menyelesaikan masalah yang diberikan oleh guru, maka terjadi peningkatan pemahaman siswa atas materi yang disampaikan oleh guru. Permasalahan yang diberikan oleh guru membuat siswa merasa tertantang untuk memecahkannya dan memberikan kepuasan untuk menemukan pengetahuan baru bagi siswa. Ketika menyelesaikan permasalahan yang diberikan oleh guru, para siswa menggunakan berbagai macam sumber bacaan yang berkaitan sehingga pengetahuan dan pemahaman mereka atas materi yang dipelajari meningkat. Siswa merasakan adanya rasa memiliki terhadap masalah yang mereka jalani, mereka berusaha keras untuk mencari jawaban atas pertanyaan mereka (Chin \& Chia, 2004).

Pada kelas kontrol, pengetahuan siswa pada materi yang dipelajari sesuai apa yang disampaikan oleh guru, karena mereka tidak memiliki tugas untuk mencari dan membaca sumber bacaan lain yang 
berhubungan dengan materi yang dipelajari. Pengetahuan dan pemahaman atas materi yang diajarkan masih rendah. Pada pembelajaran dengan menggunakan model pembelajaran konvensional guru lebih banyak mendominasi kegiatan pembelajaran, dimana terbentuk kegiatan pembelajaran yang berpusat pada guru (Munir, Damopolii, \& Iwan, 2018). PBM menjadi pembelajaran yang efisien karena siswa tidak hanya belajar, tetapi juga memperoleh pemahaman yang mendalam (Jansson, Söderström, Andersson, \& Nording, 2015). Pemahaman yang mendalam terhadap materi, membuat siswa ketika diberi posttest dapat menjawab dengan baik dengan persentase pencapaian KKM 60 lebih dari $80 \%$.

Model PBM membuat siswa yang awalnya pasif dalam pembelajaran menjadi siswa yang aktif. Siswa aktif dalam bertanya, berdiskusi, memecahkan masalah, serta menyampaikan ide dan gagasan lebih terbuka. Pemahaman konsep terhadap materi hubungan kepadatan populasi terhadap lingkungan menjadi lebih baik dengan PBM. Pemahaman konsep yang baik meningkatkan pencapaian hasil belajar siswa.

\section{SIMPULAN DAN SARAN}

Kesimpulan dalam penelitian ini adalah terdapat perbedaan hasil belajar kognitif siswa yang diajarkan dengan menggunakan model pembelajaran berbasis masalah (PBM) dengan siswa yang diajarkan dengan menggunakan model pembelajaran konvensional. Siswa dalam pembelajaran menggunakan PBM menjadi lebih aktif, dan mampu memecahkan masalah yang diberikan oleh guru dengan sangat baik.

Pada penelitian selanjutnya agar dapat menggunakan model PBM dengan mengukur hasil belajar lainnya seperti afektif dan psikomotorik. Guru dalam proses belajar mengajar hendaknya menggunakan PBM untuk memperbaiki hasil belajar siswanya.

\section{RUJUKAN}

Argaw, A. S., Haile, B. B., Ayalew, B. T., \& Kuma, S. G. (2017). The Effect of Problem Based Learning (PBL) Instruction on Students' Motivation and Problem Solving Skills of Physics. EURASIA Journal of Mathematics Science and Technology Education, 13(3), 857871.

Ayyildiz, Y., \& Tarhan, L. (2018). Problembased Learning in Teaching Chemistry: Enthalpy Changes in Systems. Research in Science \& Technological Education, 36(1), 3554. doi:10.1080/02635143.2017.136 6898

Baransano, A. Y., Yohanita, A. M., \& Damopolii, I. (2017). Penerapan Model Pembelajaran Picture And Picture untuk Meningkatkan Hasil Belajar Biologi Siswa Kelas XI IPA SMA YABT Manokwari. Seminar Nasional MIPA II Universita Papua "Konservasi, Matematika, Sains dan Teknologi" (hal. 273-280). Jakarta: Sinar Grafika.

Chin, C., \& Chia, L. G. (2004). Implementing Project Work in Biology through Problem-based Learning. Journal of Biological Education, 38(2), 69-75.

Chin, C., \& Chia, L. G. (2006). Problem-based learning: Using ill-structured problems in biology project work. Science Education, 90(1), 44-67.

Damopolii, I., Hasan, A., \& Kandowangko, N. (2015). Pengaruh Strategi Pembelajaran Inkuiri Bebas Dimodifikasi dan Kemampuan 


\begin{abstract}
Memecahkan Masalah terhadap
Keterampilan Proses Sains

Mahasiswa Pada Praktikum

Fisiologi Tumbuhan. Pancaran Pendidikan, 4(3), 191-200.
\end{abstract}

Damopolii, I., \& Nunaki, J. H. (2016). Pengembangan Media Pembelajaran Komik IPA Terpadu Materi Sistem Pencernaan pada Manusia. Pancaran Pendidikan, 5(3), 61-70.

Damopolii, I., Nunaki, J. H., \& Supriyadi, G. (2018). Effect of Problem Solving Learning Model on Students Achievement. Journal of Educational Research and Evaluation, 2(1).

Günter, T., \& Alpat, S. K. (2017). The Effects of Problem-based Learning (PBL) on the Academic Achievement of Students Studying 'Electrochemistry'. Chemistry Education Research and Practice, 18(1), 78-98.

Günter, T., Akkuzu, N., \& Alpat, Ş. (2017). Understanding 'Green Chemistry' and 'Sustainability': An Example of Problem-based Learning (PBL). Research in Science \& Technological Education, 35(4), 500-200.

Hallinger, P., \& Lu, J. (2011). Assessing the Instructional Effectiveness of Problem-based Management Education in Thailand: A Longitudinal Evaluation. Management Learning, 42(3), 279299. doi:https://doi.org/10.1177/135 0507610388596

Irawan, P., Susanna, \& Hamid, T. (2017). Perbedaan Hasil Belajar Melalui Model Problem Based Learning dan Direct Instruction Siswa Kelas X MAN Suak Timah Kabupaten Aceh Barat. Jurnal Ilmiah Mahasiswa
(JIM) Pendidikan Fisika, 2(1), 114121.

Jansson, S., Söderström, H., Andersson, P. L., \& Nording, M. L. (2015). Implementation of Problem-Based Learning in Environmental Chemistry. Journal of Chemical Education, 92(12), 2080-2086.

Kinaseh, Subekti, N., \& Pribadi, T. A. (2015). Pengaruh Model Problem Based Learning dengan Media Animasi Flash terhadap Hasil Belajar dan Aktivitas Siswa. Unnes Journal of Biology Education, 4(3), 317-321.

Kono, R., Mamu, H. D., \& Tangge, L. N. (2016). Pengaruh Model Problem Based Learning (PBL) terhadap Pemahaman Konsep Biologi dan Keterampilan Berpikir Kritis Siswa Tentang Ekosistem dan Lingkungan Di Kelas X SMA Negeri 1 Sigi. Jurnal Sains dan Teknologi Tadulako, 5(1), 28-38.

Kusumaningtias, A., Zubaidah, S., \& Indriwati, S. E. (2013). Pengaruh Problem Based Learning Dipadu Strategi Numbered Heads Together Terhadap Kemampuan Metakognitif, Berpikir Kritis, dan Kognitif Biologi. Jurnal Penelitian Kependidikan, 23(1), 33-47.

Major, C. H., \& Palmer, B. (2001). Assessing the Effectiveness of Problem-Based Learning in Higher Education: Lessons from the Literature. Academic Exchange Quarterly, 5(1). Dikutip 13 Februari 2017 dari http://www.rapidintellect.com/AEQ web/mop4spr01.htm

Munir, M. K., Damopolii, I., \& Iwan. (2018).

Pengaruh Model Pembelajaran Make a Match terhadap Hasil Belajar Siswa Di Kelas VII SMP 
Yapis Manokwari. KEGURU: Wahyudi, A., Marjono, \& Harlita. (2015). Jurnal Ilmu Pendidikan Dasar, 2(1), 120-129.

Riyanto, Y. (2010). Paradigma Baru Pembelajaran: Sebagai Referensi Bagi Pendidik dalam Implementasi Pembelajaran yang Efektif dan Berkualitas. Jakarta: Prenada Media Group.

Rusman. (2012). Model-model Pembelajaran. Jakarta: PT. Raja Grafindo Persada.

Sari, A. N., \& Harahap, N. (2015). Pengaruh Model Pembelajaran Berbasis Masalah (Problem Based Learning) Terhadap Hasil Belajar Dan Keterampilan Proses Sains Siswa pada Materi Sistem Reproduksi Manusia Di Kelas XI-PMS SMA Negeri 1 Binjai Tahun Pembelajaran 2014/2015. JURNAL PELITA PENDIDIKAN, 3(4), 29-39.

Scott, K. S. (2014). A Multilevel Analysis of Problem-Based Learning Design Characteristics. Interdisciplinary Journal of Problem-Based Learning, 8(2). doi:htps://doi.org/ 10.7771/1541-5015.1420

Slameto. (2013). Belajar dan Faktor-faktor yang Mempengaruhi. Jakarta: Rineka Cipta.

Sugiyono. (2015). Metode Penelitian Pendidikan Pendekatan Kuantitatif, Kualitatif, dan $R$ \& D. Bandung: Alfabeta.

Taşoğlu, A. K., \& Bakaç, M. (2014). The Effect of Problem Based Learning Approach on Conceptual Understanding in Teaching of Magnetism Topics. Eurasian Journal of Physics and Chemistry Education, 6(2), 110-122. Pengaruh Problem Based Learning terhadap Keterampilan Proses Sains dan Hasil Belajar Biologi Siswa Kelas X SMA Negeri Jumapolo Tahun Pelajaran 2014/2013. BIOPEDAGOGI, 4(1), 5-11.

Wijnen, M., Loyens, S. M., Smeets, G., Kroeze, M. J., \& Van Der Moles, T. (2017). Students' and Teachers' Experiences With the Implementation of Problem-Based Learning at a University Law School. Interdisciplinary Journal of Problem-Based Learning, 11(2).

Yu, B., Chan, P., Chan, S. F., \& Chang, J. (2005). Exploring The Preference in Learning Approach Among The Hong Kong University Students: Case Study, Problem-Based Or Traditional Textbook Question. Developments in Business Simulations and Experiential Learning, 32, 331-336.

Yusuf, M., \& Pujiastutik, H. (2017). Improvement of Biology Learning Results Using the Problem Based Learning Model with Environmental Media. Proceeding Biology Education Conference, 14, hal. 490493. 